\title{
THE INACCESSIBILITY OF JUSTICE FOR MIGRANT WORKERS: A CAPABILITIES- BASED PERSPECTIVE
}

\author{
Bethany Hastie*
}

This article examines the barriers migrant workers face in accessing justice, including the ability to assert legal rights in the workplace, and to access mechanisms for legal redress or remedy. Drawing on empirical research, and using the capabilities approach as a conceptual framework through which to examine these issues, this article demonstrates that the regulatory structure of the Temporary Foreign Workers Program operates to actively constrain the ability of migrant workers to assert their rights in the workplace, and seek effective legal remedies in the face of rights violations.

Cet article porte sur les obstacles auxquels se heurtent les travailleurs migrants lorsqu'ils tentent d'avoir accès à la justice, notamment en ce qui concerne les moyens d'exercer des recours en justice ou d'obtenir réparation, ainsi que sur l'écart manifeste entre les signalements de cas d'exploitation de travailleurs migrants et la jurisprudence connexe actuelle. En se fondant sur des recherches empiriques et en utilisant comme cadre conceptuel l'approche axée sur les capacités, l'auteure de cet article montre que la structure de réglementation du Programme des travailleurs étrangers temporaires restreint sensiblement la capacité des travailleurs migrants de faire valoir leurs droits au travail et d'exercer des recours juridiques efficaces lorsque leurs droits sont bafoués.

\section{INTRODUCTION}

Over 154,000 migrant workers ${ }^{1}$ held a work permit under Canada's Temporary Foreign Worker Program [TFWP] in 2015. ${ }^{2}$ Workers employed in low-wage occupations, including agricultural, caregiving, and lower-skilled occupations, totaled over 97,000 in 2015, representing nearly two thirds of all migrant workers in Canada. ${ }^{3}$ These workers are often relegated to highly precarious sectors of employment,

* Assistant Professor, Peter A Allard School of Law, University of British Columbia. This article is derived, in part, from the author's doctoral thesis, Migrant Labour and the Making of Unfreedom: How Law Facilitates Exclusion and Exploitation under Canada's Temporary Foreign Worker Programs (2015, McGill University). The author would like to thank her doctoral supervisor, François Crépeau, as well as Stefanie Carsley and Jodi Lazare, for comments on earlier drafts of this work. The author is also grateful for the insightful comments of the external reviewers of this article, and the research assistance of Elisabeth Giffin in revising this article for publication.

1 This article will use the term "migrant worker" to refer to participants under Canada's Temporary Foreign Workers Program [TFWP], as opposed to the technical label of "temporary foreign worker" which propels forward the "otherness" of this population. Fay Faraday, "Made in Canada How the Law Constructs Migrant Workers' Insecurity" (Toronto: Metcalf Foundation, 2012) at 16. See also, Judy Fudge, "The Precarious Migrant Status and Precarious Employment: The Paradox of International Rights for Migrant Workers" (2011) (Metropolis British Columbia Working Paper Series No. 11-15) at 6, n1 [Fudge, "Paradox"].

2 Immigration, Refugees and Citizenship Canada, "Facts and Figures 2015 - Immigration overview - Temporary Residents - Annual IRCC Updates, 2.3 Temporary Foreign Worker Program work permit holders by program, 2006 to 2015" online: <https://www.canada.ca/en/immigration-refugees-citizenship/corporate/reports-statistics/statistics-opendata.html> [IRCC]. This year represents the most recent statistics publicly available at the time of writing.

3 IRCC, supra note 2. 
characterized by extreme flexibility, low wages, and safety issues, such as in agriculture, food services, domestic work, construction, and hospitality. ${ }^{4}$

This article seeks to examine the barriers migrant workers face in accessing justice, conceived of as both the ability to assert legal rights in a proactive manner, and to use legal vehicles for remedy or redress. Existing research has consistently documented problematic trends regarding abuse of migrant workers under the TFWP in Canada, ${ }^{5}$ including: payment of lower wages than agreed upon; non-payment for overtime; illegal deductions from workers' wages; intentional misinformation to workers about entitlement to benefits and other legal rights; demands for long work hours with few breaks; inadequate provision of basic facilities; exposure of workers to undue health and safety risks; control over and restriction of movement of workers, and communication with others; inadequate living conditions; demands for performance of duties not agreed upon in contract; denial of medical care and other benefits; and threats of deportation. Yet, the number of reported legal cases concerning these issues remains relatively limited. ${ }^{6}$ This may be due to a wide array of factors; however, at least some instances are not

4 Samantha Dowling, Karen Moreton \& Leila Wright, "Trafficking for the purposes of labour exploitation: a literature review" online: Home Office Research Development Statistics $<$ http://www.homeoffice.gov.uk/rds $>$ at 7. See also, Bethany Hastie, "Doing Canada's dirty work: a critical analysis of law and policy to address labour exploitation trafficking" in Ato Quayson \& Antonela Arhin, eds, Labour Migration, Human Trafficking and Multinational Corporations: The commodification of illicit flows (New York: Routledge, 2012) 121 at 121.

$5 \quad$ See Bethany Hastie, "Réflexions sur les contours flous des limites entre travail domestique et servitude" (2017) 41:1 Anthropologie et Sociétés 107; Faraday, supra note 1; House of Commons, Standing Committee on Citizenship and Immigration, "Temporary Foreign Workers and Non-Status Workers" (May 2009) (Chair: David Tilson) [HOC Committee]; Law Commission of Ontario, Vulnerable Workers and Precarious Work (Toronto: December 2012) [Law Commission of Ontario]; Quebec Human Rights Commission, "Systemic Discrimination Towards Migrant Workers", summary of La discrimination systémique à l'égard des travailleuses et travailleurs migrants, adopted at the 574th meeting of the Commission, held on December 9, 2011, by Resolution COM-574-5.1.1; Alberta Federation of Labour, "Temporary Foreign Workers: Alberta's Disposable Workforce" (Edmonton: The Alberta Federation of Labour, 2007); Alberta Federation of Labour, "Entrenching Exploitation” (Edmonton: The Alberta Federation of Labour, 2009); Canadian Labour Congress, "Canada's Temporary Foreign Worker Program (TFWP): Model Program - or Mistake?" (April 2011) online: <http://ccrweb.ca/files/clc_model-program-or-mistake-2011.pdf>; Delphine Nakache \& Paula J Kinoshita, "The Canadian Temporary Foreign Worker Program: Do Short-Term Economic Needs Prevail Over Human Rights Concerns?" IRPP Study No.5 (May 2010) online: IRPP < http://irpp.org/research-studies/study-no5/ >; Anette Sikka, Labour Trafficking in Canada: Indicators, Stakeholders, and Investigative Methods, Report No.42 (Ottawa: Public Safety Canada, 2013); Kerry Preibisch, "Development as Remittances or Development as Freedom? Exploring Canada's Temporary Migration Programs from a Rights-Based Approach" in Judge Fudge et al, eds, Constitutional Labour Rights in Canada: Farm Workers and the Fraser Case (Toronto: Irwin Law, 2012) 81; Julie Kaye, John Winderdyk \& Lara Quarterman, "Beyond Criminal Justice: A Case Study of Responding to Human Trafficking in Canada" (2014) 56:1 Canadian Journal of Criminology and Criminal Justice 23 [Kaye et al]; West Coast Domestic Workers Association, Access to Justice for Migrant Workers in British Columbia (Vancouver: West Coast Domestic Workers Association, 2013), online: < http://www.wcdwa.ca/wp-content/uploads/2014/03/Access-to-Justice-forMigrant-Workers_WCDWA_FINAL_30_07_2013.pdf $>$ [WCDWA].

6 See e.g. Re Certain Employees of Sidhu \& Sons Nursery Ltd and United Food and Commercial Workers International Union, Local 1518 (2014), 241 CLRBR (2d) 1 (BCLRB); Espinoza v Canada (Attorney General), 2013 ONSC 1506; OPT v Presteve Foods Ltd, 2015 HRTO 675; PN v FR and another (No 2), 2015 BCHRT 60; Re 639299 Alberta Ltd and Meganathan, [2014] AWLD 1468, (AB ESU); Milay v Athwal, 2004 BCHRT 132; Martinez v Muir, 2016 NSLB 26; Adrian Monrose v Double Diamond Acres Limited and Jeffrey Carreiro, 2013 HRTO 1273; CSWU Local 1611 v SELI Canada Inc, 2008 BCHRT 436. See also, Devyn Cousineau, “At Risk: The Unique Challenges Faced by Migrant Workers in Canada" (Vancouver: Continuing Legal Education Society of British Columbia, 2014). 
pursued due to access to justice barriers, a factor that has also been frequently documented in existing literature. ${ }^{7}$

While the extent of the gap between workplace rights violations and enforcement is difficult to assess, that a gap does exist is supported by the existing literature on migrant workers, and more generally, workers in precarious employment. ${ }^{8}$ While existing scholarship has explored facets of the problems associated with migrant labour and access to rights in Canada, ${ }^{9}$ direct consideration of access to justice has received less independent attention. There remains a need to explore access to justice in a direct manner, and from a distinctly legal perspective, as access to courts and tribunals remains a key mechanism for enforcing legal rights in Canada, and can serve as a platform for wider reform.

Migrant workers formally possess the same employment-related rights on paper as citizen and resident workers, codified in provincial employment standards legislation, and including minimum entitlements with regards to wages, working time, vacations, termination, and other conditions of work. ${ }^{10}$ While differential rights and exclusion from standard employment protections do exist for specific jobs, ${ }^{11}$ by and large, the existence and extension of formal legal rights and protections for migrant workers is not an issue. Rather, it is the ability for migrant workers to have substantive access to their rights in practice by asserting rights, and by seeking legal remedy or redress where those rights have been violated - that represents the core issue in their ability to access justice.

This issue is not unique to migrant workers. Many workers in Canada face barriers and difficulty in accessing justice, including asserting their rights in the workplace and accessing legal mechanisms for redress or remedy when their workplace rights have been violated. ${ }^{12}$ The erosion of effective workplace

7 See Faraday, supra note 1; HOC Committee, supra note 6; Law Commission of Ontario, supra note 6; Nakache \& Kinoshita, supra note 6; Kaye et al, supra note 6; WCDWA, supra note 6; Cousineau, supra note 7; Tanya Basok, "Postnational Citizenship, Social Exclusion and Migrants Rights: Mexican Seasonal Workers in Canada" (2004) 8:1 Citizenship Studies 47 [Basok, "Post-national Citizenship"]; Leigh Binford, "From Fields of Power to Fields of Sweat: the Dual Process of Constructing Temporary Migrant Labour in Mexico and Canada" (2009) 30:3 Third World Q 503.

8 See Andrea M Noack, Leah F Vosko \& John Grundy, "Measuring Employment Standards Violations, Evasion and Erosion - Using a Telephone Survey" (2015) 70:1 Industrial Relations 86; Leah F Vosko et al, New Approaches to Enforcement and Compliance with Labour Regulatory Standards: The Case of Ontario, Canada (Toronto: Law Commission of Ontario, 2012).

9 See: Jenna Hennebry, Janet McLaughlin \& Kerry Preibisch, "Out of the Loop: (In)access to Health Care for Migrant Workers in Canada" (2016) 17 Int Migration \& Integration 521; Basok, "Post-national Citizenship", supra note 8; Binford, supra note 8; Judy Fudge \& Fiona MacPhail. "The Temporary Foreign Worker Program in Canada: LowSkilled Workers as an Extreme Form of Flexible Labour" (2009) 31 Comp Lab L \& Pol'y J 5; Sarah Marsden, "Assessing the Regulation of Temporary Foreign Workers in Canada" (2011) 49 Osgoode Hall LJ 39 [Marsden, "Assessing the Regulation"]; Nakache \& Kinoshita, supra note 6.

10 See e.g. Employment Standards Act, RSBC 1996, c113. Migrant workers are also protected by provincial human rights legislation, and occupational health and safety legislation. See also, Cousineau, supra note 7 at 5.1.12.

11 For example, differential regulations exist for both agricultural workers and domestic workers, in relation to wages, hours of work, and related topics like overtime and leaves of employment, though these exceptions are determined by occupation and not the citizenship status of the worker. See Employment Standards Act 2000, SO 2000, c41, Parts VII, VIII, IX, X, XI; O Reg 285/01 made under the Employment Standards Act 2000, sections 2(2), 4(3), 8, 9, 24-27, cited in Faraday, supra note 1, n232; Agricultural Employees Protection Act, SO 2002, c16; Labour Relations Act, RSA 2000, c L-1, s4(1)(e). See also, Fudge \& MacPhail, supra note 10 at 31; Adrian Smith, "Legal Consciousness and Resistance in Caribbean Seasonal Agricultural Workers" (2005) 20:2 Cdn JL \& Soc 95 at 101, fn22.

12 See Leah F Vosko \& Mark Thomas, "Confronting the Employment Standard Enforcement Gap: Exploring the Potential for Union Engagement with Employment Law in Ontario, Canada" (2014) 56:5 J Industrial Relations 631; David Fairey, Eroding Working Protections: British Columbia's New 'Flexible' Employment Standards, (Vancouver: Canadian Centre for Policy Alternatives, 2005); Law Commission of Ontario, supra note 6; Leah F Vosko, ed, Precarious Employment: Understanding Labour Market Insecurity in Canada (Montreal: McGill-Queens University Press, 2006); Mark P Thomas, Regulating Flexibility: The Political Economy of Employment Standards (Montreal: McGill-Queen's 
rights and protections, and enforcement mechanisms, is documented as a broader problematic trend in contemporary employment, particularly in low-wage and precarious sectors. ${ }^{13}$ These erosions have been suggested to be especially acute for workers with temporary or insecure residency status, recent immigrants, women, racialized workers, and people with disabilities who tend to be overrepresented in precarious employment sectors, more likely to experience employment standards violations, and less able to access protective measures. ${ }^{14}$

Following from the broader trends concerning employment rights access, and access to justice, this article focuses on migrant workers as a distinct population. However, this article does not seek to establish that migrant workers necessarily face greater or heightened issues of access to justice as compared to other workers in precarious jobs. Rather, it is the distinct manner in which access to justice issues intersect with the legal regulations governing migrant workers' participation under the TFWP that necessitates an independent examination of this issue. For migrant workers, access to justice issues arise, in part, from the unique regulations attending their status and experience under the TFWP, which do not similarly impact resident or citizen workers. As such, this article focuses specifically on migrant workers, and in particular, on establishing how the TFWP regulations play an active role in constraining workers' access to justice in this context.

In order to more fully understand the barriers migrant workers face in accessing justice, this article draws on empirical research to inform and illustrate the issues explored. This research was conducted as part of a larger project exploring issues related to migrant worker exploitation and the TFWP in Canada, and the role of law in facilitating exploitation and excluding migrant workers from effective protection. ${ }^{15}$ This research involved a qualitative interview study with legal actors, meaning individuals who interact with the law - interpret it, apply it, analyze it, advocate with it - in order to better understand how issues facing migrant workers are reflected in, remediated through, or complicated by law. As such, this study is limited to understanding, through qualitative interviews, the perceptions of legal actors in relation to these questions, and does not purport to document a set of "truths" or a complete picture of the issues explored. Rather, it contributes to and builds upon existing literature by adding a distinct legal lens to analyze identified issues.

University Press, 2009); Leah F Vosko, “'Rights without Remedies': Enforcing Employment Standards in Ontario by Maximizing Voice among Workers in Precarious Jobs" (2013) 50 Osgoode Hall LJ 845; Vosko et al, supra note 9; Noack, Vosko \& Grundy, supra note 9; Harry W Arthurs, Fairness at Work: Federal Labour Standards for the 21st Century (Gatineau, QC: Government of Canada, 2006).

13 See Noack, Vosko \& Grundy, supra note 9; Vosko \& Thomas, supra note 13; Fairey, supra note 13; Law Commission of Ontario, supra note 6; Mary Gellatly et al, "Modernizing' Employment Standards? Administrative Efficiency and the Production of the Illegitimate Claimant in Ontario, Canada" (2011) 22:2 The Economic \& Labour Relations Rev 81; WCDWA, supra note 6 at 19, citing also: David Fairey \& Marjorie Griffin Cohen, "Why BC's Lower-wage Workers are Struggling", The Tyee (24 April 2013), online: <http:// thetyee.ca/Opinion/2013/04/24/BC-Employment-Standards/>.

14 Noack, Vosko \& Grundy, supra note 9 at 89, citing also Nandita Sharma, "The 'Difference' that Borders Make: 'Temporary Foreign Workers' and the Social Organization of Unfreedom in Canada" in Patti Tamara Lenard \& Christine Straehle, eds, Legislated Inequality: Temporary Labour Migration in Canada (Montreal: McGill-Queen's University Press, 2012) 26; David Weil, Improving Workplace Conditions through Strategic Enforcement: A Report to the Wage and Hour Division (Boston: Boston University, 2010); Robert Wilton, "Working at the Margins: Disabled People in Precarious Employment" in Dianne Pothier \& Richard F Devlin, eds, Critical Disability Theory (Vancouver: University of British Columbia Press, 2005) 129; Grace-Edward Galabuzi, Canada's Economic Apartheid: The Social Exclusion of Racialized Groups in the New Century (Toronto: Canadian Scholars Press, 2006); Gellatly et al, supra note 14.

15 This research was undertaken in relation to the author's doctoral thesis, Migrant Labour and the Making of Unfreedom: How Law Facilitates Exclusion and Exploitation under Canada's Temporary Foreign Worker Programs (DCL Thesis, McGill University Faculty of Law 2015) [unpublished] with the approval of the Research and Ethics Board at McGill University: \#45-0712. 
The study consisted of interviews with professionals from within government, and from nongovernmental organizations, such as advocacy centres and legal aid providers. Interviews with 18 participants were conducted in British Columbia, Alberta and at the federal level in Ottawa, between February and May 2014. ${ }^{16}$ In order to best protect the anonymity and confidentiality of participants in this study, participants are identified only in terms of whether they are employed by government or nongovernmental organizations, without reference to their geographic or jurisdictional location, or organizational role. ${ }^{17}$ The study was carried out through a set of semi-structured interviews. Participants in the study were asked to direct their comments towards the low-wage streams of the TFWP, and in particular, the Stream for Low-Wage Occupations [SLO] and Seasonal Agricultural Workers Program [SAWP].

This article adopts a capabilities-based perspective as an evaluative framework through which to explore the issues migrant workers face in accessing justice. As a theory of social justice, the capabilities approach focuses attention on what individuals can do or be with the goods, resources, rights and opportunities they have. ${ }^{18}$ As Section II will unpack in greater detail, the approach is a valuable metric through which to examine how and why access to justice barriers arise, and to consider the role of law and policy in expanding or constraining access to justice for individuals in practice. The third section of this article unpacks the limitations associated with commonly identified barriers migrant workers face in accessing justice. In particular, this section addresses the issues of access to knowledge of legal rights and resources for launching a legal complaint, and draws on the capabilities approach to show how they are important, but insufficient factors in securing access to justice. The fourth and fifth sections of this article go on to explore the regulatory structure of the TFWP through a capabilities lens, to establish the significant impact this has in constraining migrant workers' access to justice. Focusing particularly on the designation of status under the TFWP, these sections illustrate how the legal regulations operate to constrain migrant workers' abilities to assert their legal rights in the workplace (IV) and to seek legal redress or remedy when those rights have been violated (V).

\section{A CAPABILITIES-BASED PERSPECTIVE ON ACCESS TO JUSTICE}

In asking about access to justice issues, it is important to begin by discussing briefly the conception(s) of justice that underpin such an examination. Two primary models dominate contemporary debates: the resourcist model of distributive justice, derived from the work of John Rawls, and the capabilities approach, derived from the work of Amartya Sen. ${ }^{19}$ A primary distinction between these two models can be summarized as whether the core criterion of measuring justice should focus on the resources and goods an individual has (or has access to), per the distributive model, or on what an individual can do, in practice,

16 Although the interviews were undertaken in 2014, the information and opinions obtained during this study bear continued relevance today, particularly concerning the core regulatory features of the TFWP. Similarly, existing procedures and vehicles for legal remedy and redress, and the barriers for individuals seeking access to those vehicles, have remained largely unchanged during this period of time.

17 See Appendix A for a list of participants (by number) and correlating designation.

18 See especially, Amartya Sen, Development as Freedom (Toronto: Random House, 1999) [Sen, Development as Freedom]; Amartya Sen, Inequality Reexamined (Cambridge, Mass: Harvard University Press, 1992); Amartya Sen, The Idea of Justice (Cambridge, Mass: Belknap Press, 2009) [Sen, Idea of Justice]; Martha Nussbaum, Creating Capabilities: The Human Development Approach (Cambridge, Mass: Belknap Press, 2011).

19 For an excellent discussion and debate of these two theories, see Harry Brighouse \& Ingrid Robeyns, eds, Measuring Justice: Primary Goods and Capabilities (Cambridge, UK: Cambridge University Press, 2010) [Brighouse \& Robbins, Measuring Justice]. 
with the bundle of resources, goods, rights and opportunities she has, and has access to, per the capabilities approach. ${ }^{20}$

Capabilities are the opportunities that individuals have to be and do things they value. In evaluating capabilities, an individual's ability to convert resources and goods into valuable doings and beings ("functionings") is central. In other words, in measuring justice "what matters [...] is what a person can do and be with the resources over which she has command," 21 having regard to the environmental context in which she finds herself. The capabilities approach is thus acutely attuned to the social, political, legal and other contexts in which an individual must navigate choice, and to how those contexts may constrain or deprive her of some quantity or quality of choice in converting the resources and goods she possesses into valued doings or beings.

The attention paid to choice and opportunity, and to the practical ability of individuals to convert resources into valuable doings and beings, is a distinct advantage that the capabilities approach offers over distributive models of justice. ${ }^{22}$ Whereas a distributive or "resourcist" approach would allocate the same "standardized package" of resources to all persons, the capabilities approach recognizes that individuals may require different, or additional, resources to achieve similar valuable doings and beings, dependent on both their internal capacities and external environments, making the capabilities approach heterogeneous and context-specific. ${ }^{23}$ For example, one of the classic examples drawn on in capabilities scholarship to establish this advantage is its ability to account for the different, or additional, resources that persons with disabilities may require to navigate community spaces. ${ }^{24}$

From a legal perspective, the capabilities approach offers two key contributions in understanding access to justice. First, the approach can acknowledge the importance of codified legal rights and the practical ability for individuals to substantively realize those rights in practice. ${ }^{25}$ The capabilities approach is concerned both with asking about what legal rights individuals have (and what capabilities they both reflect and facilitate), as well as what practical access or opportunity individuals have to use those rights to achieve valuable functionings. In this vein, the approach, as advanced by some scholars, recognizes legal rights as a capability, and enables attention to be drawn to the ways in which laws and other external

20 See Measuring Justice, ibid, for a more detailed discussion and debate of the salient similarities and differences between these two approaches, in particular: Thomas Pogge, "A Critique of the Capability Approach" 15 [Pogge, "Critique"]; Elizabeth Anderson, "Justifying the Capabilities Approach to Justice" 81 [Anderson, "Justifying the Capabilities"]. See also Nussbaum, supra note 19 at 20, and at 46-68, explaining the advantage of the capabilities approach over existing theories of development and justice.

21 Robert Salais \& Robert Villeneuve, "Introduction: Europe and the Politics of Capabilities" in Robert Salais \& Robert Villeneuve, eds, Europe and the Politics of Capabilities (Cambridge, UK: Cambridge University Press, 2004$) 1$ at 1.

22 See Anderson, "Justifying the Capabilities", supra note 21. But, see Pogge, "Critique", supra note 21 for a discussion of how distributive models might incorporate similar concerns.

23 See Nussbaum, supra note 19 at 57-58. See also Ingrid Robeyns \& Harry Brighouse, "Introduction: Social Primary Goods and Capabilities as Metrics of Justice" in Harry Brighouse \& Ingrid Robeyns, Measuring Justice, supra note 20 [Brighouse \& Robeyns, "Introduction"]; Anderson, "Justifying the Capabilities", supra note 21 at 87; Judy Fudge, "Labour as a 'Fictive Commodity': Radically Reconceptualizing Labour Law” in Guy Davidov \& Brian Langille, eds, The Idea of Labour Law (Oxford, UK: Oxford University Press, 2011) 120 at 129 [Fudge, "Fictive Commodity"].

24 This example was originally put forth by Amartya Sen in his 1979 Tanner Lecture, "Equality of What?" and formed a focal point in Sen's initial development of the capabilities approach in contrast to Rawls' theory of distributive justice: see Robeyns \& Brighouse, "Introduction", supra note 24 at 3. See also, Anderson, "Justifying the Capabilities", supra note 21 .

25 See Nussbaum, supra note 19. The relationship between legal rights and capabilities is subject to debate; see: Amartya Sen, "Human Rights and Capabilities" (2005) 6:2 Journal of Human Development 151, cautioning that while there may be substantial overlap between the concepts of human rights and capabilities, and that some human rights are rights to capabilities, there remains important distinctions between the two. Nussbaum responds to this argument at 62-68. 
factors may promote or constrain access to those rights in practice. In the context of the workplace, the approach thus highlights the importance of codified legal rights and protections for workers, ${ }^{26}$ and also offers a sharp lens through which to examine the impact of other legal or external factors on practical access to existing rights and protections for various different workers, occupations, and job sites. ${ }^{27}$ In this way, the capabilities approach assists in moving the focus of examination from the existence of legal rights (and remedies), to their efficacy in practice.

A second important contribution of evaluating access to justice through the capabilities approach is the concept of "capability security," 28 which places a duty on states to ensure substantive access to identified capabilities in practice, not only to provide formal entitlement. Thus, as Nussbaum describes, even where rights are codified in law, security entails "adequate access to the courts." 29 Considering the multitude of ways in which access to justice might be secured, this requirement of adequate access to courts could be extended to include both other remedial vehicles, as well as proactive forms of rights enforcement, such as workplace inspections and monitoring. The capabilities approach provides firm normative grounding for the requirement that these kinds of mechanisms exist and that they be effective.

The benefits of the capabilities approach make it a suitable framework for evaluating access to justice issues. In particular, its context-specific lens and focus on actual ability to convert and use resources, goods and rights in practice, support a more nuanced understanding of access to justice issues. Where barriers exist, the capabilities approach helps bring to light how myriad factors might impact on the ability to convert legal rights on paper into effective realization in practice for particular groups or individuals. Further, to the extent that barriers in accessing justice are influenced by inequalities, and vice versa, the capabilities approach provides a useful metric for understanding each, and importantly, their interrelationship. ${ }^{30}$

There are limitations and critiques to the capabilities approach. First, the approach focuses especially on individual advantage, to the potential neglect of other important criteria in assessing justice, such as the fairness or equity of processes, or the ability of citizens to utilize procedures that are equitable. ${ }^{31}$

26 See Riccardo Del Punta, "Labour Law and the Capability Approach” (2016) 32:4 Intl J Comp Lab L \& Ind Rel 383 at 395 discussing the correlation between power and capabilities, and justifying the significance of minimum guarantees concerning employment contracts.

27 For existing scholarship on the capabilities approach and labour law theory, see Simon Deakin, "The Contribution of Labour Law to Economic and Human Development" in Davidov \& Langille, supra note 24; Brian Langille, "Labour Law's Theory of Justice" in Davidov \& Langille, supra note 24; Del Punta, supra note 27. For specific applications of the capabilities approach in labour scholarship, see also: Simon Deakin \& Frank Wilkinson, "Competition, Capabilities and Rights" in Simon Deakin \& Frank Wilkinson, The Law of the Labour Market: Industrialization, Employment, and Legal Evolution (New York: Oxford University Press, 2005) 276; Kevin Kolben, “The WTO Distraction" (2010) 21:3 Stanford L \& Pol'y Rev 461; Supriya Routh, "The Judiciary and (Labour) Law in the Development Discourse in India" (2011) 44:2 L \& Politics in Africa, Asia and America 237; Supriya Routh, "Developing Human Capabilities Through Law: Is Indian Law Failing?" (2012) 3:1 Asian JL \& Econ, Article 4; Michael Orton, "Flourishing Lives: The Capabilities Approach as a Framework for New Thinking About Employment, Work and Welfare in the 21st Century" (2011) 25:2 Work, Employment \& Society 352; Virginia Mantouvalou, "Labour Rights in the European Convention on Human Rights: An Intellectual Justification for an Integrated Approach to Interpretation” (2013) 13:3 Human Rights Rev 529; Judy Fudge, “The New Discourse of Labour Rights: From Social to Fundamental Rights?” (2007) 29:1 Comp Lab L \& Pol'y J 29; Jude Browne, Simon Deakin \& Frank Wilkinson, “Capabilities, Social Rights and European Market Integration" in Salais \& Villeneuve, supra note 22, 205.

28 Jonathan Wolff \& Avner de-Shalit, Disadvantage (Oxford, UK: Oxford University Press, 2013), discussed in Nussbaum, supra note 19 at $42-45$.

29 Ibid at 43.

30 Fudge, "Fictive Commodity" supra note 24 at 133.

31 Ibid, citing Sen, Idea of Justice, supra note 19. See also Severine Deneulin \& Frances Stewart, “Amartya Sen's Contribution to Development Thinking” (2002) 37:2 Studies in Comparative International Development 61. Labour 
However, the capabilities approach continues to be developed by scholars attuned to these kinds of gaps. ${ }^{32}$ Further, the approach is often explicitly acknowledged as not being, nor intending to be, a complete theory of justice. ${ }^{33}$ A second criticism of the approach is that it does not pay sufficient attention to the social relations of exploitation. ${ }^{34}$ While this may be true of certain scholars or strands of inquiry, or of the application of the approach in some disciplines, it is not necessarily or inherently so for the approach itself, though it may present an area in need of greater attention by capabilities scholars. ${ }^{35}$ Finally, the on-going debate about whether the approach should specify a list of central capabilities, and if so, what they would be, is a source of criticism. ${ }^{36}$ However, from within law, the capabilities approach can be useful as a metric to examine existing codified rights and entitlements that may be considered as capabilities, or as necessary pieces of the bundle of resources, goods, rights and opportunities that create capabilities. In addition, the idea of access to justice can be itself considered as integral to capabilities development, given that it focuses on what avenues or mechanisms are available for individuals to convert or realize their rights in practice.

To summarize, the capabilities approach provides a rubric to examine individuals' possession of, and practical access to, a bundle of goods, resources, rights and opportunities, as well as their ability to convert those resources into valuable functionings in their daily lives. From an access to justice perspective, the approach focuses greater attention on how and why individuals do, or don't, have practical access to effectively asserting their legal rights, and provides a normative basis to obligate the state to ensure effective access to both legal rights, and legal remedies through the concept of capability security.

With this framework in mind, the next sections will turn to examine the specific issues attending access to justice for migrant workers. A capabilities-based assessment of access to justice for migrant workers under the TFWP requires understanding how various factors independently, and in concert, create barriers in accessing legal rights, and vehicles for remedy or redress. These barriers range from basic concerns

scholars have similarly critiqued the focus on "individual advantage" as neglecting the importance of collectives; see: Simon Deakin, "Social Rights in a Globalized Economy" in Philip Alston, ed, Labour Rights as Human Rights (Oxford, UK: Oxford University Press, 2005), cited also in Fudge, "Fictive Commodity", supra note 24. See also, Robeyns \& Brighouse, "Introduction", supra note 24 for an overview of the approach and dominant critiques. For a detailed critique from a distributive/resourcist perspective, see Thomas Pogge, "Can the Capability Approach be Justified?" (2002) 30:2 Philosophical Topics 167, and Pogge, "Critique", supra note 21.

32 See especially, Nussbaum, supra note 19; Wolff \& de-Shalit, supra note 29.

33 See Sen, Idea of Justice, supra note 19. See also, Anderson, "Justifying the Capabilities", supra note 21.

34 Fudge, "Fictive Commodity", supra note 24, citing also Elizabeth Anderson, "What is the Point of Equality?" (1999) 109 Ethics 287 at 336 [Anderson, "Equality"]. See also, Marianne Hill, "Development as empowerment" (2003) 9:2/3 Feminist Economics 117; Christine Koggel, "Globalization and Women's Paid Work: Expanding Freedom?" (2003) 9:2/3 Feminist Economics 163; Del Punta, supra note 27 at 394, citing also John M Alexander, Capabilities and Social Justice: The Political Philosophy of Amartya Sen and Martha Nussbaum (Burlington, VT: Ashgate Publishing Limited, 2008).

35 See Fudge, "Fictive Commodity", supra note 24 at 132 who builds upon Sen's work to incorporate a relational understanding of the individual; Del Punta, supra note 27 at 395, who briefly addresses this criticism, and the correlation between power and capabilities, citing also Anderson, "Equality", supra note 35; Hill, supra note 35; Koggel, supra note 35.

36 For example, Sen's position holds that a list of capabilities to be developed by the state should be the product of deliberative democratic debate (see Sen, Development as Freedom, supra note 19). In contrast, Nussbaum develops a list of central capabilities that broadly encompass key areas of life where the state can cultivate capabilities necessary to establish a minimally flourishing life (see Nussbaum, supra note 19). See also, Anderson, "Equality", supra note 35 concerning the concept of democratic equality, and Anderson, "Justifying the Capabilities", supra note 21, discussing its specificity within a capabilities approach to justice; Ingrid Robeyns, "Sen's Capability Approach and Gender Inequality: Selecting Relevant Capabilities" (2003) 9:2/3 Feminist Economics 61. 
regarding knowledge and resources, to complex issues created and complicated by the regulatory structure governing the TFWP, which constrain the capabilities of migrant workers to assert legal rights or seek remedies. Through the identified features discussed in this section, the capabilities approach will assist in clarifying and illustrating how the regulatory structure of the TFWP operates to constrain access to justice for migrant workers on the ground.

\section{BARRIERS IN ACCESSING JUSTICE FOR MIGRANT WORKERS: THE LIMITATIONS OF KNOWLEDGE-FOCUSED INQUIRIES}

As mentioned in the Introduction to this article, existing literature documents that migrant workers commonly experience workplace rights violations and abuses, but rarely report or pursue legal complaints in these instances. Most participants in the interview study similarly reported trends of abusive practices against migrant workers, ranging from employment standards violations to human rights abuses and physical violence, and it was commonly relayed that migrant workers are hesitant to assert their rights or pursue legal complaints when faced with abusive treatment. This evident gap between employment violations and enforcement is a broader documented trend with respect to workers in Canada and internationally, and especially for workers in precarious jobs. ${ }^{37}$

A frequently cited hypothesis for the apparent lack of complaints, or reporting, of employment-related abuses by migrant workers is that they don't have knowledge or information about their rights or the legal system in Canada. ${ }^{38}$ This section suggests that while knowledge of rights and legal resources is, indeed, an important resource in accessing justice, it is an insufficient and incomplete response. The distribution of knowledge, as a resource, is not adequate for migrant workers to access justice because there remain distinct obstacles in converting that knowledge into action.

A lack of knowledge of legal rights and available resources, or mechanisms for redress, is commonly asserted as a primary cause of migrant workers' abusive treatment and tolerance of it. ${ }^{39}$ Many participants in the interview study similarly communicated that, in their experience, migrant workers do not often have accurate knowledge of their rights and the relevant laws in Canada, and identified this as a barrier in accessing justice, as demonstrated by this quote:

I think it is extremely difficult. I think that there's very little record of success around doing it. Most of them don't even know how they would go about doing it, or whether or not they need to be doing it, because they're being taken advantage of it. It's at that level of utter ignorance, let alone those that might become aware, being able to actually act and follow through. I would say it's extremely difficult. ${ }^{40}$

37 See Vosko \& Thomas, supra note 13; Noack, Vosko \& Grundy, supra note 9; Law Commission of Ontario, supra note 6; Fairey, supra note 13; Vosko et al, supra note 9; Arthurs, supra note 13.

38 See Faraday, supra note 1; Basok, "Post-national Citizenship", supra note 8; Sikka, supra note 6; Heather Gribb, "Farmworkers from Afar: Results from an International Study of Seasonal Farmworkers from Mexico and the Caribbean Working on Ontario Farms" (Ottawa: The North-South Institute, 2006). Knowledge of employment standards, rights, and legal processes has been similarly noted as a concern with respect to other workers: Noack, Vosko \& Grundy, supra note 8 at 92-93, citing also Gellalty et al, supra note 14; Vosko et al, supra note 8.

39 See Faraday, supra note 1; Basok, "Post-national Citizenship", supra note 8; Sikka, supra note 6. For a critique of these assumptions, see Smith, supra note 12.

40 Participant 14. 
This belief was shared by a significant majority of participants in the study. As succinctly put by another participant, "it's not easy for migrant workers to enforce their labour rights, because they don't often know what they are to begin with." 41

Related to issues concerning a lack of knowledge of legal rights, some participants connected this to other knowledge-based issues, notably knowledge of available resources for assistance, and language barriers. For example, in response to a question about the level of difficulty in accessing legal remedies, another participant explained:

Probably very difficult. I mean, number one: they don't know their rights a lot of times. Number two: they don't know where to look. Number three: trying to access legal advice, it's very limited because [...] they really have no clue. [...] I just think there's a real fear that they don't have a comfort level to speak out publicly, because they're in a strange country, they don't speak necessarily the language, they definitely don't understand the law and they really don't know their legal rights as an employee. ${ }^{42}$

As illustrated by this quote, the unfamiliarity or lack of knowledge about applicable laws and rights, where to seek assistance or advice, and even language barriers, can combine to create daunting obstacles for migrant workers who may desire to seek out information or help. ${ }^{43}$

While access to knowledge is a legitimate concern for migrant workers' ability to access justice, this can also serve to deflect attention away from the complexity of issues attending situations of abusive or unlawful treatment against migrant workers. An underlying assumption that often follows from knowledge-based claims is that if workers knew or understood their rights, they would enforce them. While some, or even many, migrant workers may not have sufficient knowledge of their legal rights, others do. Access to knowledge on its own does not reflect the totality of the causes leading to abusive or unlawful treatment, nor does it explain the hesitance of migrant workers to pursue legal remedies in such situations where they are aware of their rights or the unlawfulness of the treatment they may experience.

As Smith examines, equating knowledge of legal rights with the power to enforce those rights makes two problematic assumptions about the role of law in decision-making processes: first, that educationbuilding or "learning about law and its potential" results, in a straightforward manner, in positive or desirable social outcomes; and second, that the "actions and inactions of individuals [...] are not informed by an understanding of the relative efficacy of law[.]" ${ }^{\prime 4}$ Each of these assumptions is problematic because

41 Participant 05.

42 Participant 11.

43 Some programs and policies have surfaced in response to knowledge-based concerns. For example, agricultural workers in British Columbia are required by WorkSafeBC to undergo occupational health and safety training, often provided by AgSafe (formerly FARSHA): AgSafe, "Training" online: <http://www.agsafebc.ca/training/>. See also, BC Fruit Growers Association, "Report to the 2016 BCFGA Convention from the Labour Committee" online:

$<$ http://www.bcfga.com/files/Reporttothe2016BCFGAConventionGLedit docx.pdf $>$. WorkSafeBC also partners with the Government of Mexico to provide orientation training to SAWP workers prior to travel to Canada: WorkSafeBC, "Resources for seasonal agricultural workers" online: <https://www.worksafebc.com/en/healthsafety/industries/agriculture/seasonal-agricultural-workers $>$. In Alberta, the Temporary Foreign Worker Advisory Office currently operates with the objectives of information distribution, as well as complaints assistance, and has developed a number of brochures, available in multiple languages, which outline various rights, responsibilities and other workplace issues that may be encountered: Alberta Labour, "Temporary Foreign Workers" online: $<$ https://work.alberta.ca/Immigration/temporary-foreign-workers.html>; Alberta Labour, "Information for Workers" online: $<$ https://work. alberta.ca/Immigration/workers.html>.

44 Smith, supra note 12 at 105. 
they neglect to account for the contextual and individual circumstances that necessarily factor into decision-making processes. In other words, these assumptions focus on the distribution of resources and rights, without sufficient attention to what individuals can actually do in practice with those resources and rights. The relative efficacy of law in particular may impact an individual's choice where they perceive barriers or negative consequences associated with legal options or vehicles for redress. Similarly, having knowledge of law or legal rights does not mean that an individual will understand these to be accessible, or the assertion of them to be desirable in particular circumstances. The problem is not solely one of distribution of a resource, or of access to a resource. Rather, a key obstacle lies in converting the resource (knowledge of legal rights) into valued functionings. ${ }^{45}$

It is not only knowledge of legal rights, or resources, that matters in asking and answering the question of what workers can do with their rights, or how or why they face barriers in accessing justice. The existence of rights does not mean that migrant workers can effectively access or enforce them. Relatedly, knowledge of the existence of rights should not be equated with the power to access or enforce their content. In other words, workers do not only acquiesce to exploitative or abusive conditions simply because they are unaware, and creating awareness will not equate to effective resistance to such conditions. A deeper inquiry into the surrounding contextual factors, values and needs attending individual decision-making in the context of legal rights, and the cumulative impact on an individual's ability to convert formal rights and knowledge into effective action, is necessary to understand the ability for individuals to substantively access justice. The problem for migrant workers' access to justice is not just one of distribution of resources, it is also about what workers can do with those resources, and what obstacles or constraints exist in the conversion process. The next sections take up an exploration of these deeper issues by examining the regulatory structure of the TFWP and how it produces constraints on migrant workers' practical ability to access justice.

\section{A CAPABILITIES-BASED ASSESSMENT OF THE TFWP REGULATIONS: CONSTRAINTS ON ACCESSING RIGHTS IN THE WORKPLACE}

As the previous section discussed, knowledge of legal rights and the legal system is an important, but insufficient, response to understanding how and why migrant workers face barriers in accessing justice. Knowledge of rights and resources do not, themselves, equate with effective power to enforce those rights or utilize available resources for redress.

Workers are afraid to actually exercise their rights, because exercising their rights, it means that the employer is going to - is not going to like it. That's how they say it. [...] When they have a complaint they are very hesitant, because they know that maybe for the next year they're not going to be called back. And that is - what is their crime? It's accessing their rights. It's not only a matter of accessibility and that yes in accessibility to information, and many instances they don't know that they are entitled to get, for example, workers' compensation. But when they do and they are aware, when they are informed, then it comes the issue of the risks, what it really means exercising your rights $[\ldots]{ }^{46}$

45 This is an issue that affects many workers, and not only migrant workers in Canada. For literature discussing the issues of rights-enforcement in employment more broadly, see Vosko \& Thomas, supra note 13; Noack, Vosko \& Grundy, supra note 9; Vosko, supra note 13; Fairey, supra note 13; Law Commission of Ontario, supra note 6.

46 Participant 07 . Note that being "called back" is a feature of the SAWP program where participants may be specifically named to return to their employer the following season. A similar fear of effective termination of employment may be experienced by workers under the SLO, who have a finite overall time period for employment in Canada, rather than a 
This quote hints at a more nuanced understanding of the complexity of decision-making that migrant workers may engage with when faced with abusive treatment. The issues attending access to justice for migrant workers are not only a matter of knowledge and resources. Rather, as this participant alludes to, there are "risks" associated with voicing a complaint or using legal vehicles for redress or remedy in the face of rights violations. These risks are connected to perceived negative consequences created by the regulatory structure of the TFWP, and the underlying motivations, values and needs of workers who participate in the program. In other words, as this and the next section will examine, the environmental context in which workers must navigate decision-making processes brings to light how external factors constrain the conversion process - the transformation of rights on paper into effective realization in practice. For migrant workers, a significant external constraining factor is the legal regulatory structure of the TFWP itself.

While the TFWP is comprised of several regulatory components, many of which have been documented as problematic in existing literature, ${ }^{47}$ this article focuses on the designation of work permits under the TFWP. Unlike other regulatory aspects of the TFWP that can vary by province or program category, ${ }^{48}$ the designation of work permits - based on an "employer-specific" system - is a common feature. All of the TFWP streams in Canada designate a work permit on the basis of employment for a single employer. ${ }^{49}$ This means that valid status and authorization to work in Canada is dependent on a migrant worker remaining with the employer, in the job, and at the location listed on their work permit. While procedures do exist for migrant workers to seek out alternative employment, these have been documented as largely inaccessible in practice. ${ }^{50}$ Leaving current employment, or otherwise placing that relationship in jeopardy, may leave a worker with few viable options for income-generation during their time in Canada. ${ }^{51}$ The employer-specific work permit thus creates significant dependence on an employer,

contingent, but continual, time period as exists under SAWP. See, infra note 52 concerning the existing timelines for participation under the TFWP.

47 See e.g., Faraday, supra note 1; Fudge, "Paradox", supra note 1; Sarah Marsden, "The New Precariousness: Temporary Migrants and the Law in Canada" (2012) 27:2 CJLS 209 at 217 [Marsden, "New Precariousness"]; Marsden, "Assessing the Regulation", supra note 10; Sikka, supra note 6; Quebec Human Rights Commission, supra note 6; HOC

Committee, supra note 6; Nakache \& Kinoshita, supra note 6; Basok, "Post-national Citizenship", supra note 8; Binford, supra note 8; Fudge \& MacPhail, supra note 10; Jenna L Hennebry \& Kerry Preibisch, "A Model for Managed Migration? Re-Examining Best Practices in Canada's Seasonal Agricultural Worker Program" (2010) 50 International Migration 19; Cousineau, supra note 7; WCDWA, supra note 6.

48 See for example, infra note 52 concerning different regulatory rules concerning the time and structure of participation under the low-wage streams. Access to permanent residency through Provincial Nominee Programs may also vary by province: see, generally, Delphine Nakache \& Sarah D'Aoust, "Provincial/Territorial Nominee Programs: An Avenue to Permanent Residency for Low-Skilled Temporary Foreign Workers?" in Patti Tamara Lenard \& Christine Straehle, eds, Legislated Inequality: Temporary Labour Migration in Canada (Montreal: McGill-Queen's University Press, 2012) 158. In addition, while issues concerning inspection and monitoring of employment under the TFWP is a commonly noted issue, the structure and process of inspection and monitoring can vary by province and industry. See Nakache \& Kinoshita, supra note 6 at 8, 12-21, 21-30, documenting the various overlaps and issues between federal and provincial jurisdiction on administration of the program, and employment related rights; Jenna Hennebry, "Who Has their Eye on the Ball? 'Jurisdictional Fútbol' and Canada's Temporary Foreign Worker Program" (2010) Policy Options 62; Fudge \& MacPhail, supra note 10.

49 See Immigration and Refugee Protection Regulations, SOR/2002-227, 185(b). See also, Nakache \& Kinoshita, supra note 6 at 17-18.

50 See Delphine Nakache, "The Canadian Temporary Foreign Worker Program: Regulations, Practices, and Protection Gaps" in Luin Goldring \& Patricia Landolt, eds, Producing and Negotiating Non-Citizenship: Precarious Legal Status in Canada (Toronto: University of Toronto Press, 2013) at 78; Nakache \& Kinoshita, supra note 6 at 17-18.

51 Workers have various time constraints under the TFWP, dependent on their particular stream. Employees under the Seasonal Agricultural Workers Program may come to Canada for a maximum of eight months per year: Employment and 
and can prevent a migrant worker from freely circulating in the labour market. ${ }^{52}$ This in turn produces a strong disincentive for migrant workers to assert their rights in the workplace, or in other words, creates a barrier to effective conversion of formal rights into substantive realization of just conditions of work in practice.

The limited designation of the work permit, understood in light of the difficulties migrant workers face in changing employers, as well as their time-limited participation under the TFWP, has been characterized as "bonded" 53 in nature, often giving an employer "considerable power over the employee," 54 a power produced from particular circumstances attending the TFWP which does not similarly constrain domestic workers. The power imbalance between employer and migrant worker created by the work permit system has thus been described as "the baseline of precariousness" for migrant workers. ${ }^{55}$

Because of the nature of the work permit is employer-specific, occupation-specific to the location and all that. When people come here, there's not a lot of mobility if something goes wrong with their job. [...] What you get are people who are stuck in jobs, that with employers that are either verbally abusive or exploitative, are not paying them properly. Getting them to do lots of overtime work, and they feel they can't object. They feel, they also can't move on. ${ }^{56}$

As this participant noted, the impact of the employer-specific work permit can produce a situation where a migrant worker perceives few viable alternatives to enduring abusive treatment. The constraints created by the work permit regulation make seeking out alternative employment a less than viable option in practice for migrant workers. As a result, migrant workers may "feel stuck," as the above quote describes.

From a capabilities-based perspective, the employer-specific work permit creates a distinct disadvantage for migrant workers by producing an exacerbated power imbalance in the employment relationship. This power imbalance constrains the perceived ability, or desirability, of converting formal legal rights into effective realization in the workplace. Workers who are faced with unlawful or abusive

Social Development Canada, "Hire a temporary worker through the Seasonal Agricultural Worker Program - Overview" online: <http://www.esdc.gc.ca/en/foreign_workers/hire/seasonal_agricultural/overview.page>. Workers under the Caregiver Program may have the opportunity to apply for permanent residence, but only after fulfilling either 24 months of full-time work, or 3,900 hours of full-time work, within four years from the date of arrival to Canada: Immigration, Refugees and Citizenship Canada, "Become a permanent resident - Live-in caregivers" online: $<$

http://www.cic.gc.ca/english/work/caregiver/permanent_resident.asp $>$. Until recently, workers under the Stream for Low-Wage Occupations had a finite limit on participation under the program of four years, after which time they were prohibited from participating in the program for a further four years (48 months): Immigration and Refugee Protection Regulations, SOR/2002-227, s200(3)(g). This rule was eliminated by the federal Liberal government in December 2016: Immigration, Refugees and Citizenship Canada, "Temporary Foreign Worker Program: Cumulative duration (four-year maximum eliminated) online: <http://www.cic.gc.ca/english/resources/tools/temp/work/cumulative.asp>.

52 See Marsden, "New Precariousness", supra note 48 at 217; Marsden, "Assessing the Regulation", supra note 10 at 51; Jenna Hennebry, "Permanently Temporary? Agricultural Migrant Workers and Their Integration in Canada" (2012) IRPP No 26; Binford, supra note 8 at 507; Fudge, "Paradox", supra note 1 at 5; Vic Satzewich, Racism and the Incorporation of Foreign Labour: Farm Labour Migration to Canada since 1945 (London: Routledge, 1991); Tanya Basok, Tortillas and Tomatoes: Transmigrant Mexican Harvesters in Canada (Montreal: McGill-Queen's University Press, 2002); Sharma 2012, supra note 15 at 36; WCDWA, supra note 6.

53 Marsden, "Assessing the Regulation", supra note 10 at 50.

54 HOC Committee, supra note 6 at 24. See also Nakache, supra note 51 at 77; Nakache \& Kinoshita, supra note 6 at 39.

55 Faraday, supra note 1 at 61. See, relatedly, Cousineau, supra note 7 at 5.1.12-5.1.13.

56 Participant 15. 
treatment may perceive that voicing a complaint or asserting rights in the workplace puts their employment in jeopardy, as most workers will be engaged in "at-will" employment, meaning their employer has broad discretion to terminate a worker. ${ }^{57}$ Further, migrant workers may perceive the consequences of asserting their legal rights as also affecting future income-generating opportunities under the TFWP, given the constraints noted earlier with respect to changing employers and limits on participation under the TFWP. Rather than developing capabilities and the ability for migrant workers to secure just conditions of work, the employer-specific work permit deprives workers of this capability by constraining the quality of their choice and decision-making processes through the perceived, or real, imposition of additional negative consequences associated with asserting their legal rights.

Adding to the impact of the work permit regulation on migrant workers' employment status, concerns about the possibility of deportation may create further constraints on migrant workers' capability to assert their rights in the workplace. Whether real or perceived, these concerns arise similarly from the nature of the employer-specific work permit regulation, and the perceived power imbalance it creates in the employment relationship. As one participant explains,

Well, I feel that the first barrier is the fact that the - the dilemma for the worker. This doesn't look good. Should I endure it? To what extent? What happens if I seek help? While the employer is constantly saying, 'Well, either you do this or you go back to where you came from.' So the threat is - verbalized or not - it's always in the horizon of the temporary foreign worker. He or she knows that they have to come back eventually, but everyday they stay here, it's a financial difference that has an impact in their lives and their families. So that even if they are not paid well, even if they are paid close to nothing, they still have the hope that eventually they are going to be paid. [...] So the dilemma and at what point they reach their limit of their endurance, how much I'm going to support this, to endure this abuse $[\ldots] .^{58}$

As the above quote demonstrates, migrant workers may place significant value on the security of continued employment and status in Canada, and for good reason. Given the lack of opportunity migrant workers may have for income-generating work in their home countries, coupled with the possible existence of debt and other financial obligations, they are more likely to "do everything possible to please their employers and continue in the programme." 59 Workers under the TFWP may perceive a fear of employer retaliation as not only affecting their current employment, but as impacting their long-term

57 Workers engaged in at-will employment may be terminated without cause, provided that sufficient notice (or pay in lieu of notice) is provided, see e.g. Employment Standards Act, RSBC 1996, c113, s63. The fear of employer retaliation, and of job/income loss, as a disincentive to assert rights or voice a complaint is not unique to migrant workers. Many workers may perceive similar disincentives in situations of employment standards violations or other abuse in the workplace (see Vosko \& Thomas, supra note 13; Noack, Vosko \& Grundy, supra note 9; Law Commission of Ontario, supra note 6). However, as this section discusses, the disincentive of job and income loss for migrant workers is directly connected to broader concerns surrounding their work permit, and possibly, immigration status, creating a distinct (though not necessarily worse) context for consideration. Some scholars have similarly suggested that fear of retaliation or job loss may be amplified for workers with precarious citizenship or immigration status: Noack, Vosko \& Grundy, supra note 9 at 88, citing also Vosko, supra note 13. See also, Cousineau, supra note 7 at 5.1.12-5.1.13.

58 Participant 06.

59 Binford, supra note 8 at 505; Cousineau, supra note 7 at 5.1.12-5.1.13. Workers under SAWP may be subjected to an expedited repatriation regime if terminated by their employer, making the threat of deportation and loss of future income-generation under the program a significant threat. See Faraday, supra note 1 at 93; Sikka, supra note 6 at 17; Fudge, "Paradox", supra note 1 at 25; WCDWA, supra note 6. 
immigration status and income-generation opportunities in Canada. Within that context, the potential threat of deportation, whether real or perceived, was noted by many participants as a powerful disincentive for migrant workers to assert their legal rights when faced with unlawful or abusive treatment.

The employer-specific work permit operates, then, to deprive migrant workers of the capability to assert workplace rights in a distinct manner. The considerable power that employers are perceived to hold over migrant workers' current and future employment and immigration status, created by the legal regulations, means that migrant workers may perceive the option of asserting their legal rights as diametrically opposed to maintaining both immediate and long-term income-generation opportunities under the TFWP. This creates a unique constraint on the ability for migrant workers to convert their rights into valuable functionings in practice (to make use of their formal legal rights), and is a direct product of the legal regulations attending workers' status under the TFWP. Thus, like with issues concerning knowledge of legal rights, the issue in accessing justice, in terms of asserting rights in the workplace, is not one of distribution of resources, but of what migrant workers can do with the resource - the legal rights - they possess. The employer-specific work permit renders the practical ability to use that resource largely ineffective, depriving migrant workers of the capability to access justice in the workplace.

\section{A CAPABILITIES-BASED ASSESSMENT OF THE TFWP REGULATIONS: CONSTRAINTS ON ACCESSING MECHANISMS FOR LEGAL REMEDY AND REDRESS}

While the previous section demonstrated how the legal regulations governing employment status under the TFWP operate to constrain migrant workers' capability to assert their rights in the workplace, this section carries forward the analysis of the impact of the regulations in accessing formal mechanisms for justice, namely, courts and other adjudicative bodies that can provide remedy for rights violations. This section uses the capabilities approach to inquire about the hesitancy of migrant workers to voice complaints or utilize legal vehicles for redress when faced with abusive or unlawful treatment. It thus focuses substantially on the concept of "capability security", and how the TFWP regulations produce substantial barriers in this regard.

As mentioned in Section II, the notion of "capability security" relates to ensuring that individuals have adequate access to their capabilities, and opportunities to use them, in practice. Where rights are concerned, this entails adequate access to courts or similar legal mechanisms for enforcing rights and remedying violations. The key question that naturally flows from this proposition is "what does adequate access mean"? The capabilities approach would reject a formalist response based on ostensible entitlement to use courts or other vehicles, and would inquire more deeply into the substantive access or practicability of individuals using such vehicles, or as Smith notes, the "relative efficacy" of such vehicles and the remedies they provide. This requires examining how various factors may work in concert to expand or constrain the opportunity for individuals to access and use such procedures in practice. It also requires examining how effective or aligned available remedies are in addressing the underlying values and needs of individuals contemplating legal recourse.

At the outset, it is important to note that migrant workers do face barriers in accessing legal vehicles for remedy based on formal premises, as well as substantive ones. The procedural aspects of enforcing rights and remedies through legal mechanisms can create additional obstacles for migrant workers, due to both the time and resources required to carry out legal measures. ${ }^{60}$ Because migrant workers are in Canada for only a temporary period, ${ }^{61}$ moving through adjudicative processes can be stalled or effectively

60 See Nakache \& Kinoshita, supra note 6 at 22; Cousineau, supra note 7 at 5.1.14.

$61 \quad$ See supra note 52. 
terminated when and if they have to leave Canada. In addition, having adequate support and resources to understand how to navigate legal processes is cited as an obstacle for migrant workers. ${ }^{62}$

Employment standards enforcement may be implemented through a combination of proactive investigations, employer compliance, and employee complaints. ${ }^{63}$ Existing literature suggests that as proactive investigations and monitoring have declined, so has voluntary employer compliance. ${ }^{64}$ This leaves the responsibility for employment standards enforcement largely with the employee, through the use of complaints-based mechanisms, ${ }^{65}$ which may variably include an employment standards complaints process, human rights complaint, or private lawsuit, depending on the specific situation. ${ }^{66}$ However, it is well-known that workers in many contexts, including migrant workers, will be hesitant or resistant to pursue formal legal complaints, thus leaving many workers without practical access to enforce their rights. ${ }^{67}$ The complaints-driven system is not one where migrant workers have an "effective voice." 68

The TFWP regulations, and particularly the employer-specific work permit, operate at a deeper level to constrain access to justice for migrant workers based on the very nature of legal vehicles for remedy as complaints-based processes. Just as migrant workers may have good reason to avoid asserting their rights in the workplace, these same reasons can produce a hesitancy to pursue a legal complaint in the face of abusive treatment. The existence of, and reliance on, a complaints-driven process for remedying abusive treatment was frequently cited by participants in the interview study as a substantial challenge to accessing remedies for migrant workers. Given the powerful deterrents to, and risks of complaining, as described in the previous section concerning asserting rights in the workplace, it is unsurprising that migrant workers may often decline to use legal processes. ${ }^{69}$ This is further indicative of a broader trend concerning the ineffectiveness of complaints-based mechanisms for remedying employment standards violations. ${ }^{70}$

The problems associated with complaints-based mechanisms for legal redress are compounded by the issue of complainant identification, which migrant workers may perceive as an acute risk to the security of their current and future employment and immigration status, as discussed in the previous section. As one participant explains,

62 See Hennebry \& Preibisch, supra note 48 at 30.

63 See Vosko \& Thomas, supra note 13.

64 See ibid. See also, Arthurs, supra note 13 documenting a similar decline in proactive inspection and monitoring, as well as educational initiatives, by federal labour inspectors.

65 Vosko \& Thomas, supra note 13.

66 In BC, for example, employees must follow a series of steps if they wish to file a complaint under the Employment Standards Act. See: Government of British Columbia, "Complaints Process" online:

$<$ http://www2.gov.bc.ca/gov/content/employment-business/employment-standards-advice/employmentstandards/complaint-process $>$. For commentary regarding issues related to the employment standards complaints process, see WCDWA, supra note 6 at 20, citing also: David Fairey, "Workplace Injustices", online: BC Employment Standards Coalition <http://bcemploymentstandardscoalition.com/media/letter-to-the-editor/workplace-injustices/>; Fairey, supra note 13; Gellatly et al, supra note 14. Individuals who have been discriminated against in their employment may also file a human rights complaint under provincial human rights legislation such as the BC Human Rights Code, RSBC 1996, c210. For information on the process of filing a human rights complaint, see: BC Human Rights Tribunal, "File a Complaint", online: <http://www.bchrt.bc.ca/complaint-process/complain/file.htm>. For commentary regarding the human rights tribunal process, see Cousineau, supra note 7. Finally, employees may have a claim arising in common law, such as for constructive or wrongful dismissal.

67 See Vosko \& Thomas, supra note 13. See also Vosko, supra note 13.

68 Faraday, supra note 1 at 95. See also Nakache \& Kinoshita, supra note 6 at 21-25, 39-40.

69 See Cousineau, supra note 7 at 5.1.12-5.1.13.

70 See Noack, Vosko \& Grundy, supra note 9; Vosko \& Thomas, supra note 13; Vosko, supra note 13. 
Well, we know that for any kind of employment standards complaint, whether you're a migrant worker or not, we know that there - any investigation in terms of employment standards is complaints driven. Even as a Canadian, I think it would be difficult for me to make a complaint against my employer knowing that it would be pretty obvious who made the complaint, because those processes are dependent on complaints and dependent on that person coming forward. I think it would be a challenge for anybody to make that complaint. And if you were a temporary foreign worker, with your employment tied to that employer, that also seems pretty intuitive, that it would be very challenging to come forward and make that complaint. ${ }^{71}$

As this quote illustrates, the general challenges associated with a complaints-based process may be compounded further for migrant workers who are "tied" or "bonded" to their employer, and who will have limited opportunities to seek alternative employment under the TFWP. When considered in light of the underlying values and needs of migrant workers, and the ramifications - whether real or perceived - they may face when identified by their employer as having launched a legal complaint (such as the possibility of deportation), it is unsurprising that such vehicles for seeking remedy or redress may be perceived as undesirable or ineffective solutions.

Given the requirement for a complainant to identify, and possibly cooperate further with authorities, the structure of complaints-driven processes for employment, human rights and other legal issues, is seen as a detrimental condition for migrant workers to access their legal rights and remedies in practice. Even where there exist investigations or inspections at the workplace, the issues surrounding identifiable complaints, and complainants, may present significant deterrents for migrant workers to report abusive treatment. $^{72}$ The perceived risks associated with both current and future job and income loss, considered in light of the legal regulations governing participation under the TFWP, as described in the previous section, create significant disincentives for migrant workers to pursue legal remedies, just as they do to assert rights in the workplace.

These barriers are a direct product of the TFWP regulations, and the constraints produced by the employer-specific work permit, as explored in the previous section. The regulations operate not only to constrain migrant workers' opportunities to assert their rights in the workplace, but continue to negatively impact their ability to access justice through legal vehicles for redress. The designation of status under the TFWP thus produces significant capability insecurity, because it creates considerable obstacles to accessing a wide array of rights in practice, and to obtaining remedies in the face of rights violations. In other words, the TFWP renders ineffective or impractical the opportunity to convert the legal rights and entitlements migrant workers ostensibly have in their employment relationship into meaningful and just working conditions, and into realizable remedies or compensation for workplace rights violations.

In addition to the inaccessibility of complaints-driven processes, migrant workers may be hesitant to pursue legal vehicles for redress because of the limited spectrum of remedial options available through such claims. ${ }^{73}$ While workers may receive compensation for their abusive treatment or rights violations,

71 Participant 12.

72 This has been noted as a broader trend: Noack, Vosko \& Grundy, supra note 9. In that article, the authors also acknowledge that individuals with insecure residency status are most likely to refuse reporting employment standards violations (at 92).

73 Workers may receive compensation for complaints pursued in relation to employment standards legislation (see e.g. $B C$ Employment Standards Act, ss 78-79), human rights complaints (where specific compensation, such as for lost wages, can be requested in addition to a general compensatory award for injury to dignity), and private suits addressing contractual or tort claims. In some circumstances, the law provides a remedy of reinstatement. However, it is unclear 
the existing remedial options are not likely to provide the longer-term employment and administrative security that often are core values and needs in migrants' decision-making processes in this context, as discussed earlier. Given, again, the time limitations which may be associated with a migrant worker's participation under the TFWP, they may be hesitant to leave a current employer, or place their employment in jeopardy by launching a legal claim, particularly where such a claim might result only in a compensatory award to the detriment of future income-generation opportunities in Canada. The available remedies under law will therefore not necessarily be understood to provide a meaningful or effective solution to the issues migrant workers face in accessing justice when considered in a wider context that accounts for their own motivations, values and needs.

Thinking about the remedial options as not only procedural rights associated with court processes, but as substantive opportunities, is important in advancing greater access to justice. Effective remedies can be seen, under the capabilities approach, as providing substantive opportunities to realize and engage with capabilities like decisional autonomy, bodily integrity, and others. ${ }^{74}$ This means, in turn, that effective remedies must be tailored to addressing and promoting the capabilities that are constrained or deprived of through unlawful treatment, as reflected in the particular legal claims. In other words, under the capabilities approach, we must ask about how access to justice is impacted by the perceived effectiveness of legal remedies in addressing the issues at stake. For migrant workers who face rights violations in the workplace, this requires not only compensation, but considering how mechanisms for justice can address the underlying issues concerning security of employment, administrative status, and other important values underlying migrant workers' experiences.

\section{CONCLUSION}

Using the capabilities approach, this article has sought to both provide a clearer picture of the issues relating to the gap between rights on paper and in practice for migrant workers, and to highlight the important role of the state to ensure adequate access to those rights in practice, and to remedial mechanisms where those rights are violated. Knowledge of legal rights and available resources continue to present issues for migrant workers, and can be identified as foundational capabilities necessary for accessing justice in the workplace and through legal mechanisms for remedy or redress. While knowledge of rights and resources are important capabilities to foster, and indeed some work is being done in this area, this article also makes clear that these are insufficient to address the continued inaccessibility of justice for migrant workers. Rather, an exploration of the employer-specific work permit establishes the deeper underlying issues that effectively disable migrant workers from substantively accessing the rights which they are entitled to in practice. This article has explored how the bonded nature of the work permit constrains migrant workers' capabilities to access justice. The work permit system negatively impacts the ability for migrant workers to convert their legal rights into just conditions of work by creating a distinct and exacerbated power imbalance in the employment relationship. This, in turn, creates strong

how this might apply in the context of migrant labour, where federal regulations concerning the Labour Market Impact Assessment process may impact the availability of reinstatement. For a discussion of applicable compensatory remedies in human rights complaints, and the impact that a closed work permit may have on calculating the award, see Cousineau, supra note 7 at 5.1.17-5.1.18. Note that critiques of compensatory awards as remedies are not unique to migrant labour, or employment, contexts. See e.g. Robert M Solomon et al, Cases and Materials on the Law of Torts, $9^{\text {th }}$ ed (Toronto: Carswell, 2015) at 1156-1159 for an overview of dominant critiques concerning compensation in tort law.

74 Sarah Ganty \& Moritz Baumgartel, "Effective Remedies as Capabilities: Towards a User Perspective to Human Rights of Migrants in Belgium" (2014) 8:2 Human Rights \& International Legal Discourse 215. 
disincentives to assert rights or utilize vehicles for legal remedy when considered in light of the wider context in which migrant labour occurs, and the underlying motivations and needs of migrant workers participating under the TFWP. As a result, the legal system and access to justice for migrant workers who face abusive or unlawful treatment appear to be far too often out of reach.

While this article has focused on exploring the problems facing migrant workers' access to justice, the capabilities approach is also a useful tool for thinking ahead in terms of how to create better access to justice for migrant workers, as well as more broadly for workers in precarious employment. This can, and should, include continued work in informing and educating workers on their rights and available resources in Canada. However, this article has also identified several key areas for regulatory reform. This article has demonstrated, for example, the importance of reconsidering the designation of employment status under the program, which, from a capabilities-based perspective, unreasonably constrains the opportunities for migrant workers to access and use their capabilities in practice - whether related to asserting rights in the workplace or utilizing legal mechanisms to remedy rights violations. In addition to the problematic consequences attending the work permit system, this article has alluded to issues concerning the temporary nature of employment and status, practical difficulties in accessing procedures to change employers, and a lack of consistent and proactive inspection and monitoring under the TFWP, and in employment contexts more generally. As such, this article has sought to set the stage for further research that might use the capabilities approach as a concrete tool for reimagining and evaluating regulatory and institutional reform that would create greater access to justice for migrant workers in Canada. 
Appendix A: Interview Study Participants

\begin{tabular}{|l|l|}
\hline Participant 01 & Government \\
\hline Participant 02 & Government \\
\hline Participant 03 & Government \\
\hline Participant 04 & Government \\
\hline Participant 05 & Government \\
\hline Participant 06 & Government \\
\hline Participant 07 & Non- Government \\
\hline Participant 08 & Government \\
\hline Participant 09 & Non- Government \\
\hline Participant 10 & Government \\
\hline Participant 11 & Non- Government \\
\hline Participant 12 & Non- Government \\
\hline Participant 13 & Non- Government \\
\hline Participant 14 & Non- Government \\
\hline Participant 15 & Non- Government \\
\hline Participant 16 & Non- Government \\
\hline Participant 17 & Government \\
\hline Participant 18 & Government \\
\hline
\end{tabular}

